The Discovery II observations show that the low carbon dioxide pressures are likely to be found only in the summer months: in winter the $\Sigma \mathrm{CO}_{2} / \mathrm{Cl}$ ratios were so high that even the freezing water had carbon dioxide partial pressures of at least $3 \cdot 1 \times 10^{-4} \mathrm{~atm}$.

It has not been possible in this short article to do justice to the earlier workers on the carbon dioxide problem, notably Prof. A. Krogh and J. F. McClendon, or to describe recent work in the Barents Sea and the Baltic, and more particularly Prof. Wattenberg's treatment of the Meteor observations, but enough has been said to show what great opportunities the accurate measurement of hydrogen ion concentration in the sea offers.

It may, for example, be worth while to review what has been done on the relations between animal behaviour and alkalinity in the sea, because carbon dioxide concentration may be as effective in governing shoaling and distribution as hydrogen ion concentration; there are also many outstanding problems relating to the decomposition of plankton that can be re-examined by calculating carbon dioxide concentration from hydrogen ion concentration measurements ; the Discovery Committee's data will help to solve some of them.

Carbon dioxide determinations have also geophysical and climatological interest. Since the ocean has such a tremendous capacity for carbon dioxide, it must, practically speaking, control the carbon dioxide content of the atmosphere, and where equilibrium with the surface water is established the atmospheric carbon dioxide pressure will depend to some extent on biological activity and distribution of nutrient salts ; the low carbon dioxide pressures around the polar fringes in summer give these regions an added attraction. Continental air has generally a high carbon dioxide content; but Prof. Buch shows that modern development can have very little influence on the total carbon dioxide content of the atmosphere, and his figures are refreshing, as his papers are.

\footnotetext{
${ }^{1}$ Buch, K., "Beobachtungen über chemische Faktoren in der Nordsee, zwischen Nordsee und Island sowie auf dem Schelfgebiete nördlich zwischen Nordsee und Island sowie auf dem Schelfgebiete nordlich
von Island", Conseil perm. intern. pour l'exploration de la mer.
Rapp. et proc. verbaux, 89, III, 13-31 (1934); "Beobachtungen Rapp. et proc. verbaux, 89, III, 13-31 (1934); "Beobachtungen über das Kohlensäuregleichgewicht zwischen Atmosphäre und Meer im Nordatlantischen Ozean", Acta Acad. Aboensis, Math. et
Phys., 11, 9, Abo, Finland (1939); "Kohlensäure in Atmosphäre Phys., 11, 9, Abo, Finland (1939) ; "Kohlensäure in Atmosphäre
und Meer an der Grenze zum Arktikum"; Acta Acad. Aboensis, Math. et Phys., 11, 12, Abo, Finland (1939).

Buch, K., Harvey, W. H., Wattenberg, H., and Gripenberg, S., "Utber das Kohlensäuresystem im Meerwasser", Conseil perm. intern. pour "exploration de la mer. Rapp. et proc. verbaux, the Carbonic Acid Equilibrium", Conseil perm., etc. Rapp. et proc. verbaux, 85 (1933).

"Wattenberg, H., "Kalziumkarbonat und Kohlensåuregehalt des Meerwassers", Wissenchaftliche Brgebnisse der Deutschen Atlantischen 'Expedition, 1925-27, 8 (1933).

4 NATURE, 143, 1033 (1939).

${ }^{3}$ Buch gives the reference: Lundegårdh, Henrik, "Der Kreislauf der Kohlensäure in der Natur", Jena, pp. 37-38 (1924).
}

\title{
OBITUARIES
}

\section{Sir Gilbert T. Morgan, O.B.E., F.R.S.}

GIR GILBERT MORGAN died after a very short illness on February 2 in his seventieth year. For fifty years he had been engaged in chemical research and probably no other chemist had such wide know. ledge of scientific and applied chemistry. A fitting mark of the Jubilee was the presentation to him in July last of the medal of the Society of Chemical Industry, its highest honour; on this occasion he gave an account of his career and an outline of his researches.

A professor to-day has the advantages of laboratories and equipment such as were never dreamed of by his forebears; he is more dependent than they were on his research students and collaborators. Morgan was happy in this respect; he gave full credit, developed the personal side and received the most loyal support. This in part accounts for the great volume of work accomplished.

Handsome, with alert and friendly eye, yet quiet in manner, Morgan had an amiable personality. $\mathrm{He}$ was wedded to chemistry, and when not at the laboratory bench or directing research he was to be found working for one or other of the chemical societies. In their more sociable gatherings he had the gracious assistance of Lady Morgan, née Kathleen Desborough.
Morgan was a student of Meldola at Finsbury and came under the practical teaching of Streatfield, who has influenced so many chemists. Meldola was then working on dye stuffs and consulting for Read Holliday at Huddersfield, who found a post for Morgan at the end of his college career.

Here a wide field was open for research, and among other tasks, Morgan prepared the ten dihydroxynaphthalenes, which took him four years. He relates that he condensed formaldehyde with phenol to a product which solidified to a clear amber resin. As the material had no value for making colours it was set aside. This was in 1893, and it was not until 1906 that Bakeland patented the process as a synthetic resin and made a large fortune out of it.

In 1894 Morgan became restless in industry and went back to college, graduating at the Royal College of Science under Sir William Tilden and being appointed to the staff there. In 1904 he began the fruitful co-operation with Miss Micklethwait leading to work on organic derivatives of phosphorus, arsenic and antimony.

Morgan passed on to the Royal College of Science, Dublin, where he was at the outbreak of the War of 1914-18. In 1915 he went back to his old firm, now British Dyes, for a short period to help reconstruct 
the industry. But in 1916 he returned to academic life and to Finsbury to succeed Meldola, transferring to Birmingham as Mason professor in 1919. In 1925 came what he described as "a State experiment in Chemical Research", namely the decision to form a Government Research Laboratory at Teddington under the Department of Scientific and Industrial Research, with Morgan as its first director.

It was generally felt that no one was better fitted for the task, but opinions were sharply divided as to the nature of the work which could best be carried out there. It is widely accepted now that Morgan made a success of the task, and that when he retired after thirteen years he left the Chemical Research Laboratory as an asset of real value to the nation. The work done by the Laboratory during the first few months of the War has fully justified all the hopes which Morgan had for its future, and it was a keen pleasure to him to hand over the directorship to one of his students, Dr. G. S. Whitby.

Morgan organized a variety of work at Teddington, including an installation for high-pressure reactions, a branch of chemistry then in its infancy. His interest in chemical engineering had always been strong, and he did much to develop the autoclave.

Morgan's scientific researches cover so wide a field that any reference to them in detail here is impossible for lack of space. Their very diversity prevented perhaps the highest achievement in any one field, though all were fruitful to a greater or less extent. Morgan's claim to fame rests on broader foundations. He did as much as anyone to place the science of chemistry on a sure basis in Britain. By teaching and research, by co-operation with industry, he inspired men to succeed in solving chemical problems and advanced the national status and prestige in chemistry, pure and applied.

At a moment when most men would have sought ease, he was ready to start again in a new branch of his subject as chairman of the Research Fund Committee, Institute of Brewing. He received numerous honours, a knighthood in 1936, honorary degrees at Dublin, Birmingham, St. Andrews, the fellowship of the City and Guilds Institute, to mention only a few. He was formerly president of the Chemical Society and of the Society of Chemical Industry, and an indefatigable worker on committees.

We have lost his kindly presence and the help of his clear incisive mind all too soon. A life crowded with change and incident may have caused him to live faster than some of us ; we could have wished for his ripe counsel in old age.

\section{E. F. Armstrong.}

\section{Mr. E. S. Harkness}

Mr. Edward Stephen Harkness, the American philanthropist, who died on January 30 just a week after his sixty-sixth birthday, devoted his last score of years to administering and sustaining the benefactions instituted by his mother, who founded the Commonwealth Fund in America in 1918. The Harkness fortune was made in Standard oil. It dates from about seventy years ago, at which time Stephen V. Harkness, the father, who was in a small way of business in Cleveland, Ohio, is said to have lent the daring young Rockefeller $£ 1,200$. In the present century the example set by Rockefeller in efficient philanthropy inspired the Harkness family. After the death of the father, mother and son made philanthropy their first interest. The elder Mrs. Harkness died in 1926, leaving for the Fund an endowment of about $£ 7,500,000$, which sum Edward

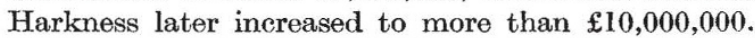
But he also bestowed large personal gifts.

Efforts of the Commonwealth Fund have taken chiefly the lines of education and of public health. In England the first major gift was the fellowships for post-graduate Britons in American universities, the counterpart to the Rhodes scholarships, except that Commonwealth fellows may proceed to any of about twelve universities in America, either between the Atlantic coast and the Mississippi, or on the Pacific coast. The stipend is $£ 600$ a year for two or three years; to date appropriations for these fellowships have reached a total of $£ 650,000$. Most of the holders have studied science in America-physics, chemistry, biology, engineering. In 1930 Harkness gave to England the Pilgrim Trust, $£ 2,000,000$, the first grant from which was given to the building fund of the Royal Institution. The five original trustees of the Pilgrim Trust still serve. A third Harkness philanthropy in Great Britain was the Child Guidance Council, a centre of information upon 'mental health' for children. Recently in Woburn House, the Council is now evacuated to Bath, and is itself at present engaged in an inquiry into "emotional and behaviour problems" of evacuees.

Grants from the Commonwealth Fund in America have taken a general medical turn, following in that subject the pattern of the Rockefeller Foundation, and contributing in the past twenty years about $£ 4,000,000$. Part of this sum has subsidized research in trachoma, leukæmia, functions of the kidneys, and bodily resistance to disease. An annual grant has been given to Dr. May Wilson's clinic in New York for rheumatic fever. Large sums have gone on one hand to the advance of medical teaching, and on the other to fellowships for young post-graduates in medicine. Harkness built ten hospitals. In these, mostly in the rural south, as in Virginia and Tennessee, he took a steady personal interest. In one area, Rutherford County, Tennessee, the Fund has for fifteen years served the cause of public health, and has strikingly reduced the death-rate there from typhoid fever, diarrhœa, tuberculosis and puerperal fever together with infant mortality. Only a fortnight before Harkness died he announced the enlargement of two of his hospitals in this region. But apart from this medical philanthropy, Harkness will be chiefly remembered in America for his great gifts to Harvard and Yale Universities-about $£ 6,000,000$ altogether-for a scheme under which those unwieldy institutions were enabled to build separate collegesseven at Harvard and nine at Yale-after the plan of Oxford and Cambridge, and at last give staff and students an opportunity to become individuals. 